\title{
Alexander Pope (1688-1744): his spinal deformity and his doctors
}

\author{
O.P. Sharma
}

\begin{abstract}
Alexander Pope (1688-1744): his spinal deformity and his doctors. O.P. Sharma. (C)ERS Journals Ltd 1999.

ABSTRACT: Alexander Pope was the towering figure of 18th century England. A poet and a wit he commanded unswerving loyalty from his friends and penetrating hatred from his enemies. His spinal deformity, either due to tuberculosis, trauma or congenital weakness, shaped his career. This brief report highlights the illness and the medical men who were involved in treating Alexander Pope. Eur Respir J 1999; 14: 1235-1237
\end{abstract}

Correspondence: O.P. Sharma, USC School of Medicine, GNII 11-900, 2025 Zonal Avenue, Los Angeles, CA 90033, USA, Fax: 12132262738

Received: June 231999

Accepted after revision June 261999

Alexander Pope was born on May 21, 1688 in London, UK where his father had a flourishing linen business on Lombard Street, London. When Pope was young, his father sold the business and moved to Binfield near Windsor, UK. There, in the lap of the lush, verdant, quiet countryside, the child grew into an attractive and handsome youngster. His early development was extraordinarily smooth. Like many gifted children, Pope was principally self-educated. He became reasonably versed in Greek and Latin. According to William Ayre (Pope's early biographer) [1], the boy composed the following verse at the age of 12 :

Happy the man, whose wish and care A few paternal acres bound,

Content to breathe his native air In his own ground.

Blest, who can unconcernedly find

Hours, days and years slide soft away. In health of body, peace of mind, Quiet by day.

Not too long after the above lines were written, Pope was trampled by a wild cow that wounded his throat and chest. Soon after this, his disfiguring spinal deformity, that was to play an important role in his life, was first noted. Many years later, Samuel Johnson wrote that either by natural deformity or accidental distortion Pope's vital functions were so impaired that his life became a long disease. The poet constantly complained of headaches and treated himself with coffee inhalations. He became chronically sleep deprived and exhausted, such that in later years he used to fall asleep and nod in company. Gradually, he became fretful, easily displeased, capricious and resentful. Sir Joshua Reynolds vividly described Alexander Pope's appearance and disability: "He was four feet, six inches high, very humpbacked, and deformed. He wore a black coat and, according to the fashion of the time, had on a little sword. He had a large and very fine eye, and a long handsome nose; his mouth had those peculiar marks which are always found on the mouths of crooked persons; and the muscles which were so strongly marked that they se- emed like small cords." [2]. Pope's friend William Wycherely, who later became his enemy, was more succinct and mean, dubbing him "a little, tender, crazy carcass" [2, 3].

\section{What was the nature of Pope's back deformity?}

Severe spinal deformities, now rare in developed countries, were common in 17th and 18th century England. Ricketts, tuberculosis, poliomyelitis, malnutrition, trauma and congenital abnormalities were prevalent.

Did ricketts cause Pope's deformity? Perhaps, not. Indeed, there is considerable disagreement as to whether or not ricketts could ever cause scoliosis. In Pope's case, there is no evidence of other rachitic manifestations (e.g., bow legs, multiple fractures, bad teeth, etc). Similarly, the theory of tuberculous as the origin of the deformity is not convincing. Spinal tuberculosis or Pott's disease, although not a complication of adult or reinfection tuberculosis, is part of the haematogenous syndrome. The pathologic process is characterized by the formation of cheesy pus, which may migrate along the psoas muscle and produces a typical "cold abscess". Pain is usually the first symptom. The clinical course is punctuated by systemic features of tuberculosis. Despite the spinal deformity, Pope maintained a good appetite, enjoyed highly seasoned meat, biscuits, and dry conserves [4]. The occurrence of respiratory and cardiac failure is rare. It is also unlikely that Pope suffered from any congenital neurologic disorders; none of the biographers mention dermatological or neuromuscular features commonly observed when scoliosis is caused by neurofibromatosis, Frederich's ataxia or poliomyelitis.

Pope's scoliosis became manifest during his adolescence. The familial incidence of idiopathic scoliosis is higher than seen in other types of spinal curvatures [5]. Pope's father also suffered from a spinal deformity. A biomechanical and radiological investigation of idiopathic scoliosis indicates that biplanar asymmetry is the essential lesion [6]. A major component of Pope's deformity was right-sided thoracic convexity, a frequent feature of idiopathic scoliosis. In patients with idiopathic 
scoliosis, the deformity is usually noticed in late adolescence, during or after the second growth spurt. A rounded hump on the back with a fixed, rigid and severe curve begins to appear. Further rotation of the spine produces grotesque deformity. The combination of true kyphosis and a lateral curvature is rare; when present, it is nearly always congenital. The time and nature of the insult during foetal life that leads to such a deformity remains obscure. In an extensive survey of 11,000 Edinburgh (Scotland) school children, scoliosis was found in 3.9 per 1,000 females and 0.3 per 1,000 males. The overall incidence of scoliosis in the UK is $\sim 1.8$ per 1,000 . A higher incidence of 4.0 per 1,000 is found in the USA. The cause of idiopathic scoliosis, whether a growth abnormality or a subclinical neurological condition, is still debated.

The symptoms are primarily related to an undesirable appearance with associated physical and psychological components. Back pain, either in the lumbar or thoracic region, can become debilitating and is now considered an indication for active therapy. In severe cases, recurrent episodes of respiratory infection and ventilatory failure lead to cor pulmonale and death [7]. Usually, respiratory problems first arise during the fourth decade of life. The treatment may be nonsurgical management with a Milwaukee brace or surgical correction by spinal fusion and reduction of the deformity by the placement of Harrington strut bars $[8,9]$. In the early part of the 18th century, there was no treatment for the condition. When Pope's condition gradually worsened with age, it led him to seek medical advice from physicians and quacks alike.

\section{His physicians/surgeons}

\section{William Cheselden}

Amongst the physicians close to Pope was William Cheselden (1688-1752), born in Somerby, Leicestershire, UK. He was the foremost surgeon of his time. He was on the active staff of St. George's, St. Thomas Hospital, the Western Infirmary, and the Chelsea Hospital, all in London [10]. He described "...a lateral operation for stone..." in 1727 which has hardly been improved upon since [10]. A skillful and exceedingly fast surgeon, he could perform a lithotomy in $54 \mathrm{~s}$. In 1728 he introduced an operation for an artificial pupil, that consisted of a simple iridotomy with a needle. He wrote two popular texts books on anatomy, The Anatomy of the Human Body and The Anatomy of the Bones. Cheselden was the first man in England to insist on the importance of a sound knowledge of anatomy for medical students. His systematic teaching of preclinical sciences involved the use of a printed syllabus. This feature was later emulated by William Hunter. A kind-hearted and genial man, he was a good boxer, an excellent draftsman and a respectable poet. It is said that one of the books of the Dunciad was written by Cheselden. He produced the plans for Old Putney Bridge and the Surgeons's Hall in the Old Bailey (London). Although, the exact nature of the cure which Cheselden prescribed Pope is not known, it sufficed for the poet to immortalize him along with Richard Mead (another of Pope's physicians) in the couplet:
I'll do what Mead and Cheselden advise

To keep these limbs and to preserve those eyes.

\section{John Arbuthnot}

John Arbuthnot (1667-1735), the son of a Jacobite minister, was born in Aberdeen, UK. He went to London, taught mathematics and wrote The Laws of Chance, a book exploring gaming. In 1694, he entered University College, Oxford, UK, but later moved to St. Andrews, Scotland (UK) to study medicine. He returned to London to practice medicine. He was elected Fellow of the College of Physicians and was appointed physician to Queen Anne.

Arbuthnot was a man of wide-ranging interests as well as an outstanding physician. His unusual literacy gifts brought him in contact with Johnathon Swift, Alexander Pope, John Gay, Robert Hardy, Earl of Oxford, Thomas Parnell and William Congreve. Although Pope was the most interesting member of the group, the harsh physical deformity had made him a irritable, petty, spiteful and mean. Arbuthnot understood it and provided tender and sympathetic influence. Arbuthnot died on February 27, 1735. He is buried in St. James' Church, Piccadilly, London. Pope paid this grateful tribute to Arbuthnot:

Friend to my life! (which did you not prolong)

The World had wanted many an ideal song.

\section{John Joshua Ward}

John Joshua Ward, also called "Spot" on account of a claret mark on one side of his face, was one of the famous quacks of 18th century England. He made his fortune by selling antimony pills, drops, a dropsy purging powder, and other concoctions. He won the confidences of George II by reducing the King's dislocated thumb with a sharp wrench. For his services he was exempted from the penalties of the Parliamentary Act of 1748. "Spot" Ward is in William Hogarth's painting, "Company of Undertakers," which was painted in 1736. Pope remembered him in the couplet:

Of late, without the least pretence of skill Ward's groom a famed physician by a pill.

\section{John Radcliffe}

John Radcliffe, son of a lawyer, was born December, 1652 in Wakefield in West Riding, Yorkshire, UK. He spent 19 of his 64 yrs in Oxford, 5 of them as a student at University College, 7 as a fellow of Lincoln College and 7 in medical practice in the city. In 1684 he left Oxford for London. Radcliffe's style of clinical practice was close to that of Thomas Sydenham. He opposed any and every kind of violent treatment. One of the more successful cures attributed to him was for smallpox patients. Against the prevailing procedure of keeping the patient in a closed and heated room, Radcliffe prescribed fresh air with Sydenham's cooling regimen. To the young Pope, he recommended fresh air and exercise [11].

\section{Richard Mead}

Richard Mead (1673-1754) was born in Stepney, a small village near London, in August 1673. He studied 
medicine in Holland and Italy. In 1707, his diploma for doctor of physics from Padua, Italy was confirmed by the University of Oxford. In 1716, he was admitted fellow of the College of Physicians and delivered the Harveian Oration in 1723 [12].

Richard Mead inherited the practice of John Radcliffe, his mentor, who told him "I'll tell you a sure secret to make you a fortune, use all mankind ill." However, Mead himself was a scholar and a gentleman; he was also one of the most successful practitioners of his time, making as much as 7,000 pounds sterling in a single year. "Dr. Mead....", said Samuel Johnson, "....lived more in the broad sunshine of life than almost any man" [11].

Pope's adversaries took advantage of his physical disability and ugly deformity. However, he had the medical, intellectual and fraternal support of his physician friends. In the 17th and 18th centuries, when therapeutic options were limited, medicine men and quacks alike followed the age-old Hippocratic dictum: "...as to diseases, make a habit of two things; to help or at least not to harm." [13].

\section{References}

1. MacNalty AS. Alexander Pope (1688-1744). Poet and cripple. Proc Royal Soc Med 1958; 51: 601-604.
2. Papper EM. The influence of chronic illness upon the writings of Alexander Pope. J Royal Soc Med 1989; 82: 359-361.

3. Sowerby R. Alexander Pope: selected poetry and prose. London: Routledge, 1988.

4. Johnson S. Rasselas, Poems and Selected Prose. New York, USA, Holt, Reinehart and Winston, 1958; pp. 306.

5. Wynne-Davies R. Familial idiopathic scoliosis. A familial survey. J Bone Joint Surg 1968; 5OB: 24-27.

6. Dickson R, Lawton J, Archer I, Bult W. The pathogenesis of idiopathic scoliosis. Biplanar spinal asymmetry. J Bone Joint Surg 1984; 66: 8-15.

7. Bergofsky EH, Turino GM, Fishman A. Cardiorespiratory failure in Kyphoscoliosis. Medicine 1959; 38: 263-280.

8. Anonymous. Respiratory function in scoliosis. Lancet 1985; 1: 84-85.

9. Harrington FR. Treatment of scoliosis: correction and internal fixation by spine instrumentation. J Bone Joint Surg 1962; 44(a) 591: 634.

10. Cope Z. William Cheselden 1688-1752. Edinburgh and London, E S Livingston Ltd, 1953.

11. Quinton A. Dr John Radcliffe, the benefactor and his benefactions. J Roy Soc Med 1986; 79: 380-386.

12. Richard Mead. The Medical Works. London, C. Hitch and L Hawes, 1762.

13. Daintith J, Isaacs A. Medical quotes: a thematic dictionary. Oxford, UK, Market House Books Ltd., Facts on File, 1989; p. 204. 